\title{
Two new species of Endothia
}

\author{
Takao KoBAYAsHi and Kazuo ITō*
}

During recent years, the writers have collected many specimens of Endothia inhabiting various kinds of broad-leaved trees and classified them into seven species. Among them five were identified as the following hitherto known species: Endothia parasitica (Murr.) P. J. et H. W. Anderson, E. singularis (P. et H. Sydow) Shear et Stevens, E. fluens (Schw.) Shear et Stevens, E. havanensis Bruner and E. tropicalis Shear et Stevens, but the other two are considered as new to the science. In this paper, the writers describe these two new species of Endothia with brief supplementary notes.

\section{Endotria japonica sp. nov.}

Stromatibus corticola, sparsis v. dense gregariis, "Deep Chrome" v. "Cadmium Yellow"; peritheciis globulosis, $280-600 \mu$ in diam.; collis nigris, erumpentibus, $480-1390 \mu$ longis; ascis subclavatis v. oblongo-ellipticis, 43-66 $\times 7-11 \mu$, octosporis; ascosporidiis irregulariter biseriatis, ellipticis v. obovoidis, utrinque rotundatis, hyalinîs, uniseptatis, ad septum constrictis, (9)-10.5$12.5-(17) \times(3.5)-4-4.5-(5.5) \mu$.

Hab.: On the bark of stem of dead or living Quercus grosseserrata B1. (Mizu-nara) and $Q$. glandulifera B1. (Ko-nara).

Distribution: Japan (Honshû).

Materials: On Quercus grosseserrata (Mizu-nara)-Meguro, Tokyo, May 19, 1954, coll. by T. Kobayashi (TYPUS) ${ }^{1}$; Mt. Ōtake, Tokyo, May 23, 1954, coll. by T. K.; Mt. Togakushi, Nagano Pref., July. 18, 1954, coll. by T. K.; Higashine, Yamagata Pref., Aug. 6, 1954, coll. by T. K.; Mt. Zaô, Yamagata Pref., Aug. 7, 1954, coll. by T. K.; Narusawa, Yamanashi Pref., Sept. 23, 1954, coll. by T. K.; Agematsu, Nagano Pref., Oct. 11, 1955, coll. by T. K.,; Wada, Nagano Pref., Oct. 13, 1955, coll. by T. K. On Q. glandulifera (Ko-nara)-Kanô, Nagano Pref., Oct. 24, 1954, coll. by T. K.; Hinoharu, Yamanashi Pref., April 19, 1955, - oll. by T. K.

Notes: Perithecia are irregularly embedded in the lower portion of the stroma and usually 50 or more in number. The present species is very near in type to Endothia tropicalis among the already known species. But it has larger asci and ascospores than the latter, distinguishing both sufficiently to classify them
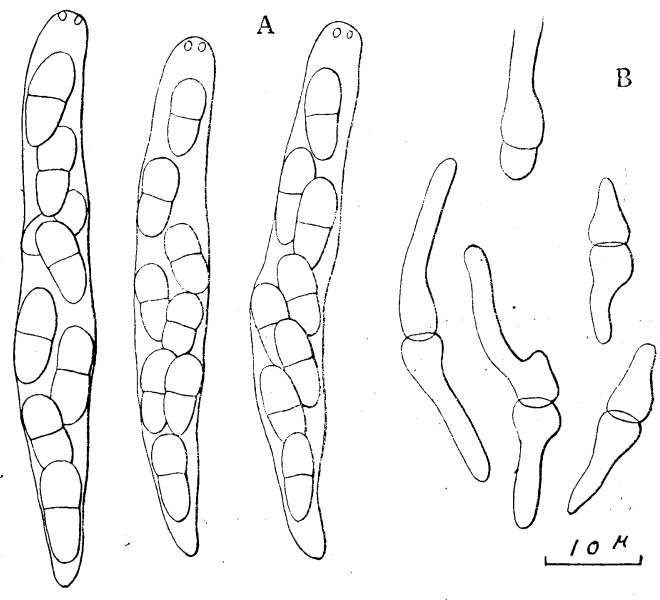

Fig 1. Endothia japonica sp. nov.

A. Asci and ascosporés

B. Germinating ascospores

into different species. In E. tropicalis, asci are 40-50 $\times 7 \mu$ and ascospores are 7.5-10.5 $\times 3.5-$ $5 \mu$, mostly $8-10 \times 4-4.5 \mu$, whereas in our fungus the sizes are respectively as follows: $43-66 \times$ 7-11 $\mu$ and 9-17 $\times 3.5-5.5 \mu$, mostly $10.5-12.5 \times 4-4.5 \mu$.

In culture on potato sucrose agar, the fungus grows flatly and has yellowish orange ("Orange" to "Cadmium Yellow") colored mycelium on which a few pycnidial bodies are produced.

* Laboratory of Forest Pathology, of the Government Forest Experiment Station, Meguro, Tokyo, Japan.

1) The type specimen is deposited in the Herbarium of the Government Forest Experiment Station, Meguro, Tokyo, Japan. 
2. Endothia macrospora sp. nov.

Stromatibus corticola, sparsis v. dense gregariis, "Orange"; peritheciis globulosis $340-580 \mu$ in
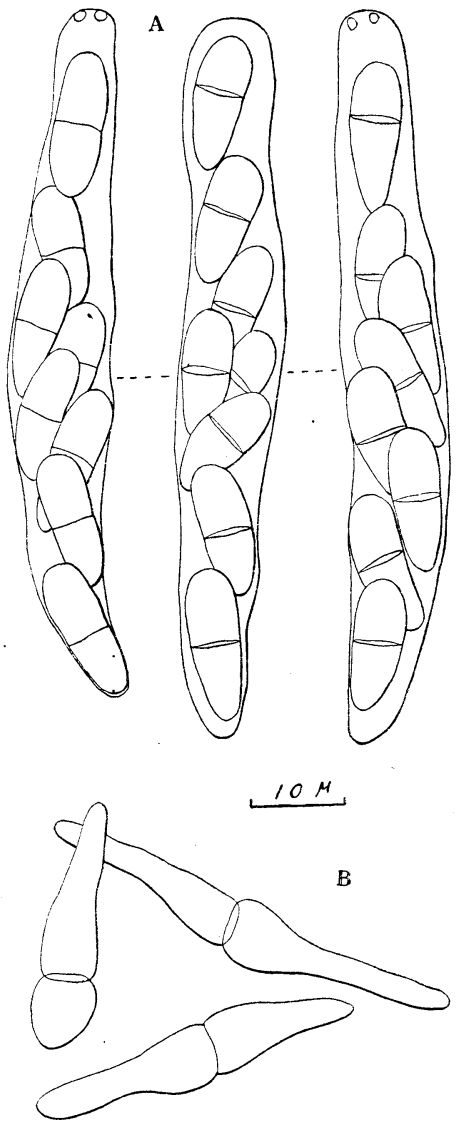

Fig 2. Endothia macrospora sp. nov.

A. Asci and ascospores

B. Germinating ascospores diam.; collis nigris erumpentibus $790-1090 \mu$ longis; ascis oblongo-subclavatis $\mathrm{v}$. oblongo-ellipticis, $62-73 \times 10-11 \mu$, octosporis; ascosporidiis irregulariter biseriatis, ellipticis, hyalinis, uniseptatis, ad septum constrictis, $14-18 \times 5-5.5 \mu$; pycnidiis stromaticis, irregulariter cavitatis; conidiis oblongis, hyalinis, $3.5-4.5 \times 0.7-1.1 \mu$.

Hab.: On the bark of dead Shiia Sieboldii Makino (Shii) (Shinagawa, Tokyo, June 22, 1954, by T. Kobayashi(TYPUS).

Distribution; Japan (Tokyo).

Notes: Perithecia are irregularly embedded in the lower portion of the stroma, usually 50 or more, and has open conical ostioles on the surface of the stroma with black slender necks. In this species asci and [ascospores are far larger than those of all the other species of the genus.

One-month-old cultures on potato sucrose agar are flat and have pinkish yellow ("Bittersweet" or "Pinc" to "Salmon Orange") mycelium on which the viscosious conidial masses are pushed out from a few large pycnidia.

The writers wishto express their sincere thanks to Mr. Rokuya Imazeki, Chief of Protection Division of the Station, for his advice and critical editing of the Latin diagnoses. Their thanks are also lextended to Mr. Michio Nakagawa for help in preparation of the illustrations.

(Received April 23, 1956)

\section{Literature}

1) Anderson, P. J. \& H. W.: Phytopath., 2: 261 262. (1912).

2) Bruner, S. C: Mycologia, 8: 239 242. (1916).

3) Clinton, G. P: Phytopath., 2: 265 269. (1912).

4) : Ann. Rept. Connec. Agr. Exp. Sta., 1912 : 359 453. (1913).

5) Farlow, W. G: Science n. s., 35: 717 722. (1912).

6) Saccardo, P. A: Syll. Fung., 1: 600. (1882).

7) : Ibid., 9:700.(1891).

8) : Ibid., $14: 550 \sim 551 .(1899)$.

9) : Ibid., $17: 675 .(1905)$.

10) : Ann. Myc., $4: 273 .(1906)$.

11) : Syll. Fung., 24:760 762. (1928)

12) Shear, C. L., Stevens, N. E. \& Tiller, R. J: U. S. Dept. Agr. Bull., 380: 1 82. (1917).

13) Sydow, H. \& P.: Ann. Myc., 10: 82. (1912).

14) Viziolii, J : Mycologia, 15: 115 116. (1923). 